\title{
The effect of intracerebroventricular infusions of ghrelin on the secretory activity of the GnRH/LH system in peripubertal ewes
}

\author{
A. Wójcik-Gładysz¹, M. Wańkowska, A. Gajewska, T. Misztal, M. Szlis and J. Polkowska
}

The Kielanowski Institute of Animal Physiology and Nutrition, Polish Academy of Sciences, 05-110 Jabłonna, Poland

KEY WORDS: hypothalamus, pituitary, $\mathrm{GnRH}, \mathrm{LH}$, ghrelin, peripubertal ewes

Received: 17 July 2014

Revised: 27 October 2014

Accepted: 28 November 2014

${ }^{1}$ Corresponding author:

e-mail: a.wójcik@ifzz.pl

\begin{abstract}
Ghrelin is a 28-amino acid orexigenic peptide, synthesized mainly by cells located in the stomach mucosa, that can be also engaged in modulation of reproductive functions. The aim of this study was to investigate the effect of intracerebroventricular (icv) infusion of ghrelin on the secretory activity of the gonadotropin hormone releasing hormone/luteinizing hormone $(\mathrm{GnRH}$ ) LH) system in peripubertal ewes. The animals were randomly divided into three groups: 1. standard fed, 2. starved for $72 \mathrm{~h}$, and 3. standard fed + icv infused with ghrelin. Infusions were performed during three consecutive days; blood samples were collected on day 0 and day 3. Ghrelin infusions and short-term starvation increased the accumulation of immunoreactive (ir) $\mathrm{GnRH}$ material in the median eminence $(P<0.001)$ and ir LH material in the secretory granules of pituitary cells $(P<0.001)$ in the fasted and ghrelin-infused groups. The short starvation resulted in a decrease of mean LH plasma concentrations $(P<0.05)$ between days 0 and 3 of infusion, which was related to a lower pulse amplitude. After the icv ghrelin infusion, significant $(P<0.05)$ changes in LH pulse amplitude and frequency, but not in LH concentrations were observed. The obtained results revealed that in peripubertal ewes, exogenous ghrelin administration affects the $\mathrm{GnRH} / \mathrm{LH}$ axis mainly at the level of neurohormone/protein accumulation and LH pulsatility modifications. Ghrelin action at the hypothalamuspituitary axis is likely involved in the endocrine network that integrates energy balance and fertility in immature sheep.
\end{abstract}

\section{Introduction}

Proper development and function of the reproductive axis are crucial for survival of the species and, for this reason, they are subjected to very precise regulation by both the central nervous system (CNS) and by peripheral signals affecting the hypothalamic-pituitary-gonadal (HPG) axis (Schwartz, 2000; Tena-Sempere and Huhtaniemi, 2003). Reproductive functions are highly energy consuming, therefore, sophisticated mechanisms have been selected during evolution to allow for the reduction of HPG axis activity under energy insufficiency. Several neuroendocrine factors like neuropeptide $\mathrm{Y}$, leptin, insulin and kisspeptin interact in the physiological control of energy balance and reproductive processes (Wańkowska et al., 2002; Fernandez-Fernandez et al., 2006; TenaSempere, 2007; Wójcik-Gładysz et al., 2009). Ghrelin is a 28 -amino acid hormone identified as an endogenous ligand for the growth hormone secretagogue receptor (GHS-R) type 1a (Kojima et al., 
1999). Apart from its GH-releasing effect, several other physiological actions of ghrelin have been reported. Ghrelin stimulates food intake, regulates glucose metabolism, secretion and motility of the gastrointestinal tract, and affects pancreatic and cardiovascular functions (Lorenzi et al., 2009). Although the main source of ghrelin is the oxyntic cells in the gastric mucosa, the proximal intestine, pancreas, pituitary and hypothalamus also produce ghrelin (reviewed in Muccoli et al., 2011). Recent data show that within the CNS, the hypothalamus is the main production site of this hormone and that circulating ghrelin is able to cross the blood-brain barrier (Angelidis et al., 2013).

It is well established that ghrelin is an orexigenic hormone that is involved in the regulation of energy homeostasis, promoting food intake and weight gain (Korbonits et al., 2004). By affecting the activation of genes encoding agouti-related peptide (AgRP) and neuropeptide Y (NPY), as well as by its impact on proopiomelanocortin (POMC) neuron activity, ghrelin is a potent regulator of energy homeostasis (Cowley et al., 2003). Ghrelin and leptin act in an opposing manner (Wynne et al., 2005), and both hormones are crucial for deciphering the energy status required for the maintenance of an organism's homeostasis (Nakazato et al., 2001; Shintani et al., 2001). In this respect, ghrelin acts as a signal of starvation or energy insufficiency. It is well recognized that a negative energy balance may lead to delayed puberty onset or its lack and, consequently, to reproductive disorders (Schwartz, 2000). Nevertheless, the mechanisms that link reproductive processes and body energy reserves have not been fully explored; it is known, however, that endocrine signals governing energy homeostasis, such as NPY, leptin and orexins, are also involved in the control of reproductive function by acting at different levels of the HPG axis (Wańkowska et al., 2002; Barreiro et al., 2004; Wójcik-Gładysz et al., 2009). It has been suggested that ghrelin is involved in the regulation of reproductive function (reviewed in Lorenzi et al., 2009) based on the systemic effects it exerts at both at the hypothalamus and pituitary (Fernández-Fernández et al., 2004; Angelidis et al., 2013) and gonadal levels (Miller et al., 2005; Harrison et al., 2008). Moreover, ghrelin and its receptor, GHSR-1a, are expressed throughout the HPG axis of humans, rodents (Lorenzi et al., 2009), and sheep (Miller et al., 2005).

So far, most of the data available on ghrelingonadotropic connections is from studies on rat models and the available results still remain ambiguous. Moreover, only very limited data, based mainly on changes in the gonadotropin releasing pattern, are available for ruminants. We hypothesized that under normal metabolic circumstances, ghrelin is involved in the regulation of the HPG axis in peripubertal ewes. Therefore, the aim of this study was to evaluate the effects of ghrelin in immature sheep just prior the first ovulation on the accumulation of immunoreactive (ir) GnRH material in the hypothalamus and ir LH material in the pituitary, on LH $\beta$ mRNA expression in the pituitary, and on the peripheral plasma LH concentration and pattern. The expression of GnRH in hypothalamic neurons and LH in the gonadotropic cells of the adenohypophysis was examined using immunohistochemical and in situ hybridization and RT-PCR techniques. LH profiles in the blood plasma were investigated radioimmunologically (RIA).

\section{Material and methods}

\section{Animals and management}

The experimental procedures were approved by the Local Ethics Committee according to the Polish Guide for the Care and Use of Animals (2007, 2012). The experiment was performed on peripubertal (7-month-old) Polish Merino ewes. The animals ( $\mathrm{n}=30$ average body weight $32.3 \pm 2.8 \mathrm{~kg}$ ) were maintained indoors under natural lighting conditions $(528 \mathrm{~N}, 28 \mathrm{E})$ and fed a pelleted concentrate diet with hay and water available ad libitum. Beginning at 6 months of age, peripheral blood samples for monitoring the progesterone concentration in blood plasma were taken weekly by venipuncture, and then every two days in the last week of experiment; ovaries were examined post-mortem. One month prior to the first infusion, cannulae were implanted into the third ventricle of the brain. Before cannulation, the animals were injected subcutaneously (s.c.) with $0.05 \mathrm{mg} \cdot \mathrm{kg}^{-1}$ body weight atropine (Polfa, Warsaw, Poland), and 15 min later with pentobarbital (Vetbutal, Biowet, Pulawy, Poland), which was administered intravenously (i.v.) at a dose of $10-20 \mathrm{mg}$. $\mathrm{kg}^{-1}$ body weight until surgical levels of anaesthesia were reached. The anaesthetized animals were fixed in a stereotaxic apparatus as described before (Traczyk and Przekop, 1963). Permanent stainlesssteel guide cannulae $(0.6 \mathrm{~mm})$ were inserted into the third ventricle of the brain (position: anteroposterior $31 \mathrm{~mm}$, lateral $0.5 \mathrm{~mm}$, along the sagittal plane 0.10 ) using the stereotaxic coordinate system of Welento et al. (1969) and secured to the skull with dental cement and screws. Each guide tube was fitted with an indwelling stilette to prevent backflow of the 
cerebrospinal fluid. The correct placement of the guide cannula was established by the efflux of cerebral spinal fluid upon removal of the guide-tube stilette after the surgery and before infusion. Additionally, the placement of the guide cannula was checked by inspection of the brain after decapitation. After the surgery, penicillin-streptomycin (Scan-Vet Poland) $0.04 \mathrm{ml} \cdot \mathrm{kg}^{-1}$ body weight was given s.c. over four consecutive days.

\section{Experimental design}

The immature sheep were randomly divided into three groups ( $\mathrm{n}=10$ per group). Two groups were fed a standard diet, hay with commercial concentrates, and the third one was fasted for $72 \mathrm{~h}$. Intracerebroventricular (icv) infusions of Ringer-Locke solution, $120 \mu \mathrm{l} \cdot \mathrm{h}^{-1}$ were given to one standardfed group and fasted group. The second standardfed group received icv ghrelin $(25 \mu \mathrm{g} / 120 \mu \mathrm{l} / \mathrm{h}$ at a total daily dose of $100 \mu \mathrm{g}$. Ghrelin (human ref. 3913; Bachem, Zurich, Switzerland) was administered in a series of four $1-\mathrm{h}$ infusions from 08.30 to $14.00 \mathrm{~h}$ at $30 \mathrm{~min}$ intervals for three consecutive days using a CMA 100-microinjection pump (CMA/ Microdialysis AB, Stockholm, Sweden). One day before the infusions (day 0) and on the day of the third infusion (day 3), blood samples were collected from 08.00 to $14.00 \mathrm{~h}$ every $10 \mathrm{~min}$. Samples were centrifuged and plasma was stored at $-20^{\circ} \mathrm{C}$ until analysed for progesterone and LH. The origin of the ghrelin used and its infused dose were based on the results of Iqbal et al. (2006), who showed that in increasing plasma GH concentration in ovariectomised sheep, human ghrelin was more potent that ovine ghrelin synthesized by Osaka Peptide Institute. This observation was confirmed in our laboratory using intact prepubertal lambs (Polkowska et al., 2011). Immediately after the last infusion, the sheep were weighed and then slaughtered by decapitation under pentobarbital anaesthesia with an i.v. injection of sodium pentobarbitone $\left(20 \mathrm{mg} \cdot \mathrm{kg}^{-1}\right.$ BW; Biochemie GmbH, Kundl, Austria) in a local licensed abattoir.

\section{Real-Time RT PCR}

Immediately after decapitation, five pituitaries (from the first half of the sheep in each group) were isolated, immediately frozen in liquid nitrogen and stored at $-80^{\circ} \mathrm{C}$ until further processing (next five, from the second half of the sheep in each group, were used for IHC). Total RNA was extracted using a NucleoSpin RNA II kit (Macherey-Nagel, Duren, Germany) according to the manufacturer's instru-ctions. The yield of isolated RNA was estimated spectropho- tometrically from absorbance at $260 \mathrm{~nm}$, its purity was checked based on the A260/A280 and A260/A230 ratios (Nanodrop, USA), whereas its integrity was evaluated electrophoretically by separation on $1.5 \%$ agarose gel (InVitrogen). All samples exhibited sharp bands of $28 \mathrm{~s}$ and $18 \mathrm{~S}$ rRNA. For cDNA synthesis, $800 \mathrm{ng}$ of RNA in a total volume of $20 \mu \mathrm{l}$ was retro transcribed with the use of DyNAmoSYBR Green 2-step qPCR kit (Finnzymes, Finland) according to the manufacturer's protocol. Pairs of primers specific for glyceraldehyde-3-phosphate dehydrogenase (oGAPDH - reference gene) and the oLH $\beta$ gene were originally developed using Primer3 software (The Whitehead Institute, Boston, MA). The primer sequences spanned over intron sequences and were synthesized by Genosys Sigma (Germany). The respective sequences were as follows:

oGAPDH Gen Bank Acc. No. NM_001034034(F):

TGACCCCTTCATTGACCTTC $(\overline{\mathrm{R}})$ :

GATCTCGCTCCTGGAAGATG;

oLH $\beta$ Gen Bank Acc. No. X52488 (F):

AGATGCTCCAGGGACTGCT, (R): GATGCTGGTGGTGAAAGTGA.

Real-Time PCR was carried out using SYBR Green 2-step qRT-PCR kit (Finnzymes, Finland) components in a total volume of $20 \mu \mathrm{l}$. One tube contained: $10 \mu \mathrm{l}$ Master Mix; $7 \mu 1$ of RNA-se free $\mathrm{H}_{2} \mathrm{O} ; 2 \mathrm{x} 1 \mu \mathrm{l}$ primers $(0.5 \mathrm{mM})$ and $1 \mu \mathrm{l}$ of cDNA template. Amplification was performed on a Rotor Gene 6000 (Corbett Research, Australia) according to the following protocol: $95^{\circ} \mathrm{C}$ in 10 min for Hot Start Thermus brockianus DNA polymerase and then PCR including 38 cycles at $94^{\circ} \mathrm{C}$ for $15 \mathrm{~s}$ (denaturation), at $56^{\circ} \mathrm{C}$ for $20 \mathrm{~s}$ (annealing) and at $72^{\circ} \mathrm{C}$ for $30 \mathrm{~s}$ (elongation). Negative controls without reverse transcriptase were included in each reaction. For each cDNA sample, q-RT PCR was performed two times in triplicate. To evaluate the specificity of amplification, a final melting curve analysis under continuous fluorescence measurements was performed after completing the reaction. Obtained amplicon size and purity were checked electrophoretically on $2 \%$ agarose gel. The identity of PCR products was then confirmed by direct sequencing (Genomed, Poland). All data were analysed using Rotor Gene 600 software 1.7. To compensate for variation in cDNA concentrations and the PCR efficiency between tubes, an endogenous control of GAPDH was included and used for normalization of each sample. Results are presented as relative gene expression of the target LH gene vs expression of GAPDH. Values represent means \pm SEM for each group. The data were analysed statistically using the Mann-Whitney $U$ test at the $P \leq 0.05$. 


\section{Preparation of probes}

LH $\beta$-sense and anti-sense riboprobes were produced using previously obtained homologous sheep double-stranded cDNAs (D'Angelo-Bernard et al., 1990; Pelletier et al., 1992, 1995). The cDNAs (533 bp oLH-cDNA) were digoxigenin (DIG) labelled by in vitro transcription with SP6 and T7RNA-polymerase using the DIG-labelling kit from Roche Molecular Biochemicals (Meylan, France) and pGEM-TEasy vectors (Promega, Charbonnieres, France). The specificity of probes was confirmed by the absence of a positive signal in sections hybridized with sense probes (data not shown).

\section{Hybridohistochemistry}

Cellular LH $\beta$ mRNA expression was evaluated by using in situ hybridization in combination with immunohistochemical detection of DIG. Paraffinembedded pituitary sections were mounted on slides and coated with 3-aminopropyltriethoxysilane (2\% in acetone; Sigma, St. Louis, MO, USA). The nonradioactive in situ hybridization procedure using DIG-labelled cDNA probes was performed according to the Breitschopf et al., (1992) protocol, with minor modifications by Wańkowska et al. (2002). Briefly, slides were deparaffinised, rehydrated, washed in PBS, fixed with $4 \%$ paraformaldehyde in PBS and treated with $0.25 \%$ acetic anhydride in $100 \mathrm{mM}$ TEA buffer (triethanolamine-Cl; Sigma). Next, the sections were treated with $200 \mathrm{mM} \mathrm{HCl}$, then with $1 \%$ proteinase K (ICN, Aurora, OH, USA) dissolved in Tris-EDTA, and finally washed in Tris-glycine buffer. Sections were subsequently pre-hybridized and in situ hybridization with DIG-dUTP antisense or sense RNA probes diluted 1:100 was carried out at $55^{\circ} \mathrm{C}$ in a humid chamber. After incubation, slides were washed in $2 \times \mathrm{SSC}$ and treated with $4 \mu \mathrm{l}$ $20 \mathrm{mg} \cdot \mathrm{ml}^{-1}$ RNase A (Sigma) in $2 \mathrm{ml} 0.5 \mathrm{M} \mathrm{NaCl}$, $10 \mathrm{mM}$ Tris- $\mathrm{HCl}$ (pH 8.0), $10 \mathrm{mM}$ EDTA. Next, the sections were treated with 30\% formamide (Sigma) and washed in $2 \times \mathrm{SSC}$. The sections were washed in $100 \mathrm{mM}$ Tris- $\mathrm{HCl}$ (pH 7.5), $150 \mathrm{mM} \mathrm{NaCl}, 0.5 \%$ blocking reagent (Boehringer, Mannheim, Germany). Next, the sections were incubated with alkaline phosphatase anti-DIG antibody (Boehringer, Mannheim), diluted 1:500 in the same buffer. The sections were then washed in $100 \mathrm{mM}$ Tris- $\mathrm{NaCl}$ ( $\mathrm{pH} 7.5), 150 \mathrm{mM}$ $\mathrm{NaCl}$ and in $100 \mathrm{mM}$ Tris- $\mathrm{HCl}(\mathrm{pH} 9.5), 100 \mathrm{mM}$ $\mathrm{NaCl}$ and $50 \mathrm{mM} \mathrm{MgCl}$. Finally, the sections were incubated in buffer containing $75 \mathrm{mg} \cdot \mathrm{ml}^{-1} \mathrm{NBT}$, $50 \mathrm{mg} \cdot \mathrm{ml}^{-1}$ BCIP (Boehringer, Mannheim, Germany) and $10 \mathrm{mM}$ levamisole (Sigma, St. Louis, USA). The colour reaction was stopped in water, and slides were mounted in glycerol-gelatine (Sigma).
Controls were prepared using RNase pretreatment. Sections were incubated with RNase (Sigma), 1 unit $\cdot 100 \mu 110 \mathrm{mM}$ Tris-HCl buffer, $\mathrm{pH} 7.9$, per section, just prior to the addition of the hybridization buffer. The sections were incubated with RNase for $30 \mathrm{~min}$, and then slides were washed with $4 \times$ SSC. Controls did not exhibit any staining (data not shown).

\section{Immunohistochemistry (IHC)}

Immediately after decapitation, brains from half of the sheep in each group were perfused via both carotid arteries with $1500 \mathrm{ml} 0.1 \mathrm{M}$ phosphate-buffered saline (PBS) and subsequently with $2000 \mathrm{ml} 0.1 \mathrm{M}$ PBS containing $4 \%(\mathrm{w} / \mathrm{v})$ paraformaldehyde $(\mathrm{w} / \mathrm{v})$, $\mathrm{pH}$ 7.4. The hypothalami and the pituitaries of half of the sheep from each group were dissected $20 \mathrm{~min}$ after the beginning of perfusion and postfixed for $72 \mathrm{~h}$ (hypothalami) or $48 \mathrm{~h}$ (pituitaries) by immersion in the same fixative and washed with $0.01 \mathrm{M}$ PBS. Hypothalami jointly with the median eminence (ME) were cryoprotected in a $20 \%$ sucrose solution in $0.1 \mathrm{M}$ PBS at $4{ }^{\circ} \mathrm{C}$ for at least two days. The pituitary glands were immersed in Bouin buffer (a mixture of $4 \%$ paraformaldehyde with picric acid and glacial acetic acid) for $48 \mathrm{~h}$. The hypothalamic blocks were frozen at $-10^{\circ} \mathrm{C}$ and cut on a cryostat (Jung CM 1500, Leica Instruments GmBH, Nussloch, Germany) in coronal planes at $30 \mu \mathrm{m}$ thickness between the septum and the mammillary body, through the diagonal band of Broca, the area preoptica, the organum vasculosum of the lamina terminals, the anterior hypothalamic area, the medial basal hypothalamus including the median eminence (ME) and the pituitary stalk. The hypothalamic nuclei were identified using the atlas of the sheep brain developed by Welento et al. (1969). Then sections were processed for immunohistochemistry. Pituitaries were dehydrated in graded alcohol, embedded in Paraplast ${ }^{\mathbb{B}}$ and cut at $4 \mu \mathrm{m}$ thickness in the sagittal plane. All of the sections taken from all of the sheep were run in a single assay. Brain sections were washed in $0.1 \mathrm{M}$ PBS and then incubated for $4 \mathrm{~h}$ in $1 \%$ hydrogen peroxide in $0.1 \mathrm{M}$ PBS, $24 \mathrm{~h}$ in $3 \%$ pre-immune lamb serum in $0.1 \mathrm{M}$ PBS and in $0.5 \%$ Triton X- 100 in $0.01 \mathrm{M}$ PBS for $30 \mathrm{~min}$. The pituitary sections were deparaffinised, rehydrated, washed in $0.01 \mathrm{M}$ PBS, incubated for $30 \mathrm{~min}$ in $2 \%$ pre-immune lamb serum in $0.01 \mathrm{M}$ PBS and $30 \mathrm{~min}$ in $0.1 \%$ hydrogen peroxide in $0.01 \mathrm{M}$ PBS.

The hypothalamic sections were incubated with primary antiserum, GnRH no. 11175 (MP Biomedicals, Santa Ana, California, USA) diluted 1:2000 for $72 \mathrm{~h}$ at $4^{\circ} \mathrm{C}$, and the pituitary sections 
were incubated with primry antiserum anti-pLH $\beta$ no. 19526 diluted 1:400 for $48 \mathrm{~h}$ at $4^{\circ} \mathrm{C}$. Antibodies were kindly donated by Dr M.P. Dubois from INRA (Nouzilly, France). The methodological details and the specificity of these antibodies were described by Dubois and Dubois (1974). After the incubation with primary antibodies, the sections were rinsed in $0.01 \mathrm{M}$ PBS, incubated for $2 \mathrm{~h}$ at room temperature $\left(+20^{\circ} \mathrm{C}\right)$ with secondary antibody (sheep antirabbit Ig $[\mathrm{H}+\mathrm{L}]$ labelled with peroxidase (BioRad, France), at a dilution of $1: 40$ in $0.1 \%$ normal lamb serum in $0.01 \mathrm{M}$ PBS. The colour reaction was developed by incubating sections with $0.05 \%$ 3'3-diaminobenzidine tetrahydrochloride chromogen (Sigma) and $0.001 \%$ hydrogen peroxide in $0.05 \mathrm{M}$ Tris buffer. Selected hypothalamic material was additionally stained by the silver intensification method of Liposits et al. (1984).

As a control reaction, the inhibition of anti-hormone serum with its homologous antigen was used. Preincubation of GnRH antiserum with $10 \mu \mathrm{g} \cdot \mathrm{ml}^{-1}$ synthetic GnRH (UCB, Belgium) and LH antiserum with $4 \mu \mathrm{g} \cdot \mathrm{ml}^{-1}$ synthetic rLH32V02 (National Hormone and Peptide Program, Torrance, CA, USA) blocked the immunostaining. Antigens and antisera were mixed and pre-incubated for $24 \mathrm{~h}$ at $4^{\circ} \mathrm{C}$ before being used. Neither control exhibited any specific staining (data not shown).

\section{Image and statistical analyses}

A Nikon type 104 projection microscope (Nikon Corporation, Yokohama, Japan) was used for histological analyses of hypothalamic and pituitary sections. Staining was analysed using a Lucia version 3.51ab image analysis computer system (Laboratory Imaging Ltd. Prague, Czech Republic). Immunostained sections were projected by camera $(\mathrm{Pa}-$ nasonic KR222, Matsushita Electric Industrial Co., Osaka, Japan) to a colour monitor. Pictures were adjusted for optimal contrast, converted to grey, fixed at the same brightness levels and saved in a buffering system. Quantitative analysis was performed for each hypothalamus and anterior pituitary gland in the sub-areas of interest using a threshold function to select a range of grey values that were optically identified as positive staining. All other values were referred to as nonstaining. Before measurements, the images were processed by subtraction of background and removal of artefacts. The threshold value was different for the ME and the adenohypophysis, but constant for all measured pictures of one histochemical product. Frame size was kept constant for the duration of the image analysis. The analyses for statistical purposes were performed with an $\times 4$ objective for the nerve terminals in the ME and an $\times 40$ objective for the ir and hybridized pituitary LH cells. The parameter of area fraction indicating the percentage of stained elements in a delineated area was analysed for ir GnRH nerve terminals in the ME and ir LH-cells in the adenohypophysis. The analysis of percentage area, for immunoproduct in the ir GnRH nerve terminals was estimated in the delineated area containing the structure of the ME, extending from its rostral to caudal aspects. Measurements were performed in every $4^{\text {th }}$ section ( 20 sections per animal) in a total area of $100 \mathrm{~mm}^{2}$ for each hypothalamus. The ir and hybridized LH cells were analysed in the four sections of each adenohypophysis, using every $40^{\text {th }}$ mounted and stained section (16 fields of $0.0837 \mathrm{~mm}^{2}$ measured in each section). The quantitative measurements taken from each section for each median eminence or adenohypophysis were averaged to obtain a mean estimate for each ME or adenohypophysis for each animal. The mean data were then pooled to represent three experimental groups. The data were analysed by one-way analysis of variance (ANOVA) followed by the post hoc Tukey test and the t-test using Statistica 3.0 PL software (StatsSoft Inc. Tulsa, OK, USA). The data are reported as the mean percentage \pm SEM of the total area that exhibited positive staining. Significance was defined at the $P<0.001$ level.

\section{Determination of progesterone and $\mathbf{L H}$ in peripheral blood plasma}

The concentration of progesterone was assayed in duplicate $100-\mu 1$ aliquots by a direct RIA method routinely used in our laboratory according to the procedure described by Stupnicki and Kula (1982) with a sensitivity of $6.2 \mathrm{pg} \cdot \mathrm{ml}^{-1}$. The intra-assay coefficient of variation was $<10 \%$.

The concentration of $\mathrm{LH}$ was determined in duplicate $100 \mu \mathrm{l}$ aliquots by a routine double antibody radioimmunoassay (RIA) procedure using anti-ovine LH, anti-rabbit gamma globulin antisera and bovine LH standard NIH-LH-B6 according to Stupnicki and Madej (1976). The assay detection limit was $0.06 \mathrm{ng} \cdot \mathrm{ml}^{-1}$ of sample. The coefficient of variation calculated for control samples at concentrations of 1 and $5 \mathrm{ng} \cdot \mathrm{ml}^{-1}$ of LH was $10 \%$ and $4 \%$, respectively.

The mean concentration of LH for individual animals was calculated from the area under the curve (the sum of trapezoid areas between the curve and the abscissa). Pulse characteristics of LH were calculated using the Pulsar Computer Program developed by Merriam and Wachter (1982) and adapted to operate on an IBM-PC. The cutoff parameters $G(\mathrm{n})$ were set to a $5 \%$ error rate 
assuming a normal distribution of data. Analyses were performed individually for each sheep and included the entire sampling period. The effect of fasting or treatment on LH concentrations was analysed by one-way analysis of variance (ANOVA) followed by the leastsignificant differences test using the Stastistica 5.5 PL computer programme $\left(\mathrm{StatSoft}^{\circledR}\right.$, Inc. Tulsa, OK, USA). Data are presented as mean \pm SEM for statistical analysis, significance was defined at the $P<0.05$ level.

\section{Results}

\section{Ovarian status}

Blood plasma progesterone concentrations did not exceed $0.5 \mathrm{ng} \cdot \mathrm{ml}^{-1}$, no corpora lutea were found in any of the ovaries checked and dominant follicles were up to 6-7 $\mathrm{mm}$ in diameter.

\section{Immunoreactivity of GnRH in the median eminence of the hypothalamus}

Immunoreactive GnRH was detected anterior to the caudal part of the ME in all treatment groups. However, intensity of staining differed, demon- strating abundant presence of ir GnRH in ghrelintreated and fasted sheep compared with moderate expression in standard-fed sheep (Figures 1 A, B, C). Further computer quantitative analysis of percent area occupied by ir GnRH terminals confirmed significantly a higher $(P<0.001)$ percent of area positively stained for $\mathrm{GnRH}$ in both fasted and ghrelin-infused groups as compared with the standard-fed group (Figure $3 \mathrm{~A}$ ).

\section{Pituitary LH $\beta$ mRNA expression}

As presented in Figure 2, LH $\beta$ mRNA expression remained at the same level in all examined groups, as determined by real-time PCR. Also in situ hybridization with anti-sense probes for $\mathrm{LH} \beta$ mRNA followed by IHC detection of DIG confirmed that the population of LH $\beta$ mRNA-positive cells and intensity of the signal did not differ among all analysed groups (Figure 1 D, E, F). Moreover, histomorphometric analysis revealed a lack of significant differences in the pituitary area occupied by gonadotrops containing in situ hybridized $\mathrm{LH} \beta$ mRNA in the standard-fed, fasted and ghrelininfused groups (Figure 3 B).

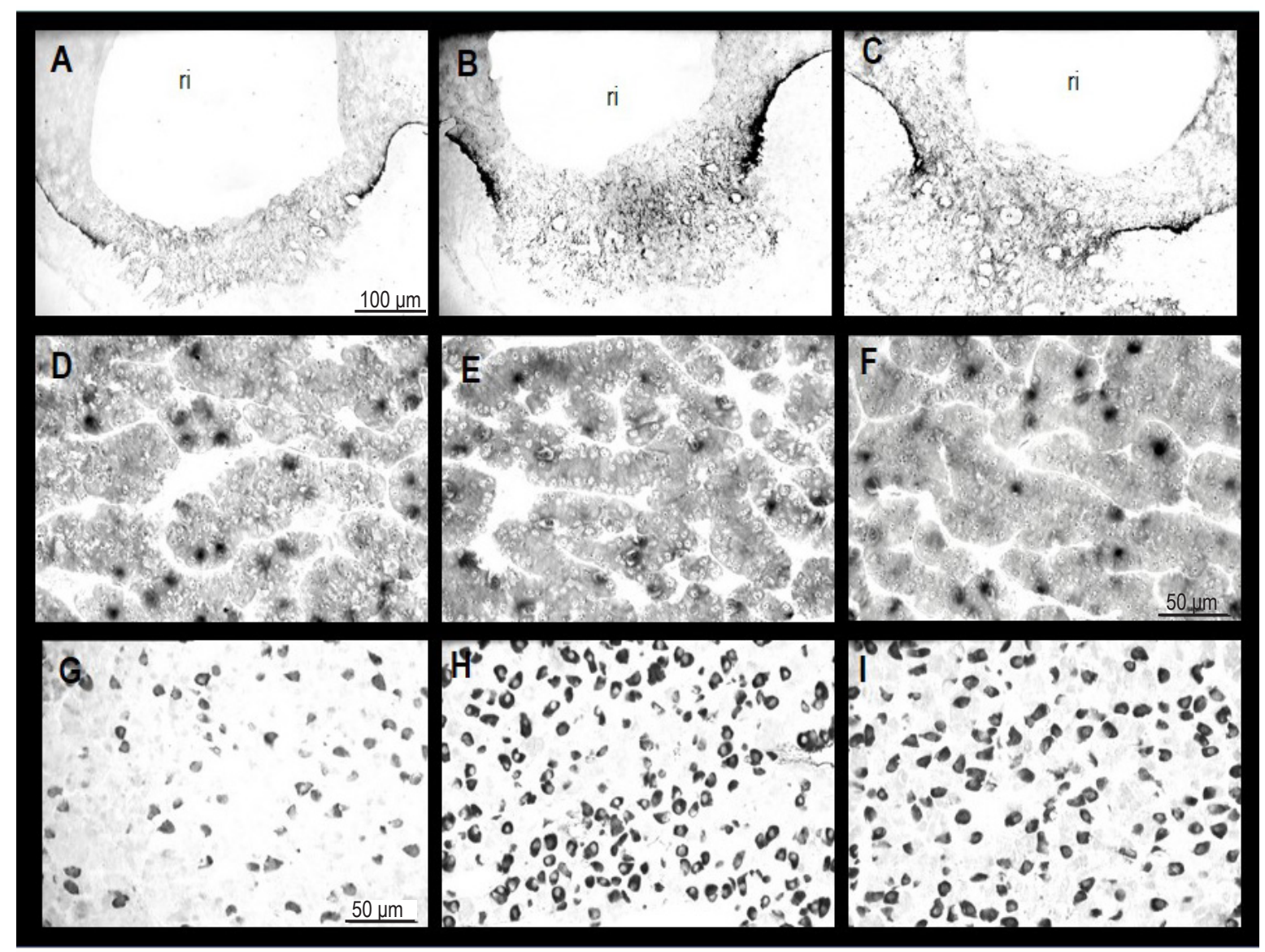

Figure 1. Immunoreactive $\mathrm{GnRH}$ in nerve terminals of the median eminence (A, B, C), LH $\beta$ mRNA transcript in adenohypophyseal gonadotrops $(D, E, F)$, immunoreactive LH $\beta$ protein in adenohypophyseal gonadotrops $(G, H, I)$ in representative standard fed (left and right panels) and fasted (middle panel) sheep receiving an intracerebroventricular infusion either vehicle (left and middle panels) or ghrelin (right panel), $\mathrm{ri}-$ recessus infundibularis, scale bars: $\mathrm{A}-\mathrm{C}=100 \mu \mathrm{m}$ and $\mathrm{D}-\mathrm{I}=50 \mu \mathrm{m}$ 


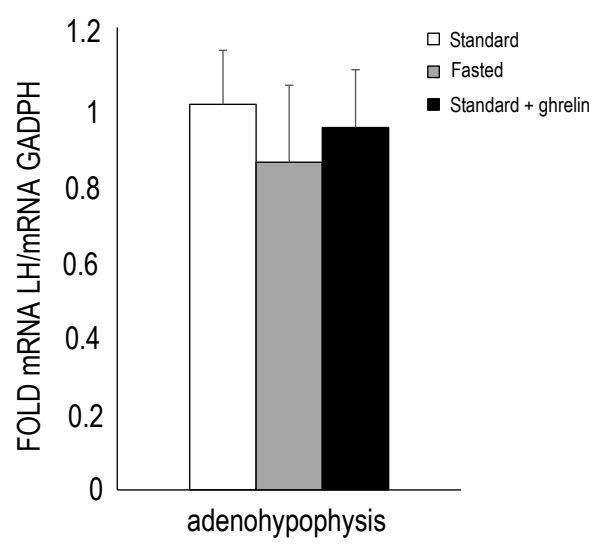

Figure 2. Levels of LH $\beta$ mRNA in sheep fed either a standard diet and infused with vehicle or ghrelin or fasted $72 \mathrm{~h}$ and infused with vehicle relative to GAPDH mRNA. Means \pm SEM

As a control, no detectable hybridohistochemical signal was observed in sections treated with sense probes for LH $\beta$-mRNA (results not shown).

\section{LH immunoreactive cells}

In the adenohypophysis, the area stained positively for the presence of LH $\beta$ and the intensity of the immunostaining were greater in both fasted and ghrelin-infused sheep compared with the standardfed ones (Figures $1 \mathrm{G}, \mathrm{H}, \mathrm{I}$ ). Changes were reflected by the augmentation $(P<0.001)$ in the percentage of area occupied by LH-cells within the adenohypophysis of fasted and ghrelin-infused groups compared with the standard-fed group (Figure $3 \mathrm{C}$ ).

\section{LH plasma concentration and pattern of pulsatility}

Before infusion (day 0), LH pulsatile parameters, i.e. mean LH plasma concentration, pulse amplitude, and LH pulse frequency, were similar in all groups of animals (Table 1). However, between days 0 and 3 , the mean plasma LH concentrations decreased $(P<0.05)$ in the fasted group of animals as compared with standard-fed sheep. This decrease was also related to a lower pulse amplitude observed in the fasted group of animals $(P<0.05)$.

After completing infusions (day 3), the mean LH concentration remained at the same level both in the standard-fed and ghrelin-treated groups. Differences were found in the pattern of pulsatility parameters, since ghrelin application resulted in enhanced pulse amplitude LH $(P<0.05)$ with concomitant lowering of pulse frequency $(P<0.05)$. The patterns of pulse parameters from sheep representative for each group are presented in Figure 4.
A

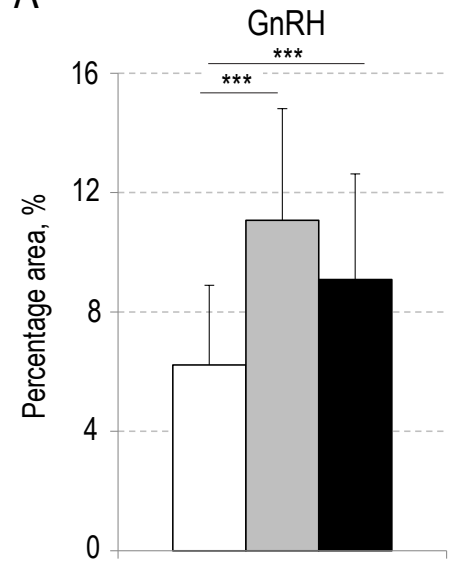

B

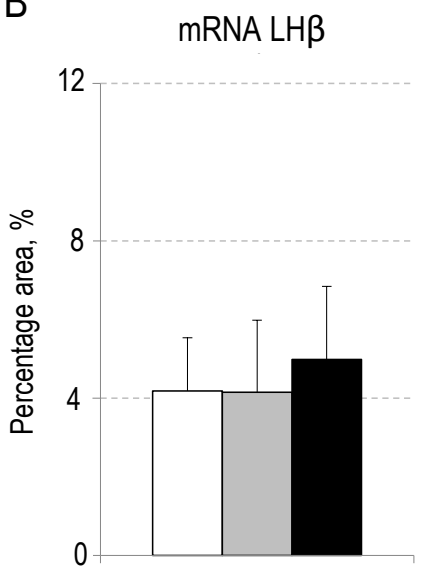

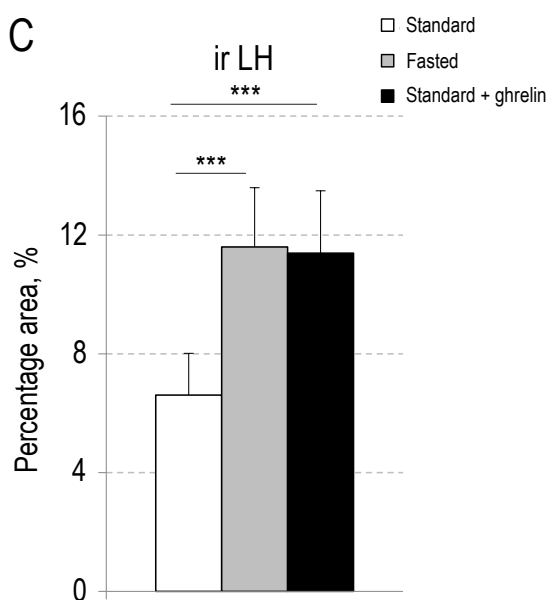

Figure 3. Percentage of total area exhibiting positive staining for $\mathrm{GnRH}$ in the median eminence $(A)$ and for $\mathrm{LH} \beta \mathrm{mRNA}(\mathrm{B})$ and ir $\mathrm{LH}(\mathrm{C})$ in the gonadotrops of sheep fed either a standard diet and infused with vehicle or ghrelin or fasted $72 \mathrm{~h}$ and infused with vehicle. Means \pm SEM; * significantly different at $P<0.001$

Table 1. Parameters of pulsatile LH release on day 0 and day 3: mean concentration, pulse amplitude and pulses frequency

\begin{tabular}{lllll}
\hline \multirow{2}{*}{ Indices } & \multirow{2}{*}{ Day 0} & \multicolumn{2}{l}{ Day 3} & standard + ghrelin \\
\cline { 2 - 5 } & & standard & fasted & $7.85 \pm 1.06$ \\
\hline Mean concentration, ${\mathrm{ng} \cdot \mathrm{ml}^{-1}}^{*}$ & $8.07^{\mathrm{a}} \pm 0.28$ & $8.06 \pm 0.56$ & $7.10^{\mathrm{a}} \pm 1.19$ & $2.96^{\mathrm{c}} \pm 1.81$ \\
Pulse amplitude, $\mathrm{ng} \cdot \mathrm{ml}^{-1}$ & $2.06^{\mathrm{b}, \mathrm{c}} \pm 1.16$ & $2.04 \pm 0.69$ & $1.82^{\mathrm{b}} \pm 0.72$ & $3.25^{\mathrm{d}} \pm 1.27$ \\
Pulse frequency, pulse/6 $\mathrm{h}$ & $4.01^{\mathrm{d}} \pm 0.55$ & $4.67 \pm 1.40$ & $4.25 \pm 2.19$ & \\
\hline
\end{tabular}

values are presented as means $+/-\mathrm{SEM} ;$; $, \mathrm{b}, \mathrm{c}, \mathrm{d}$ significantly different at $P<0.05$ 

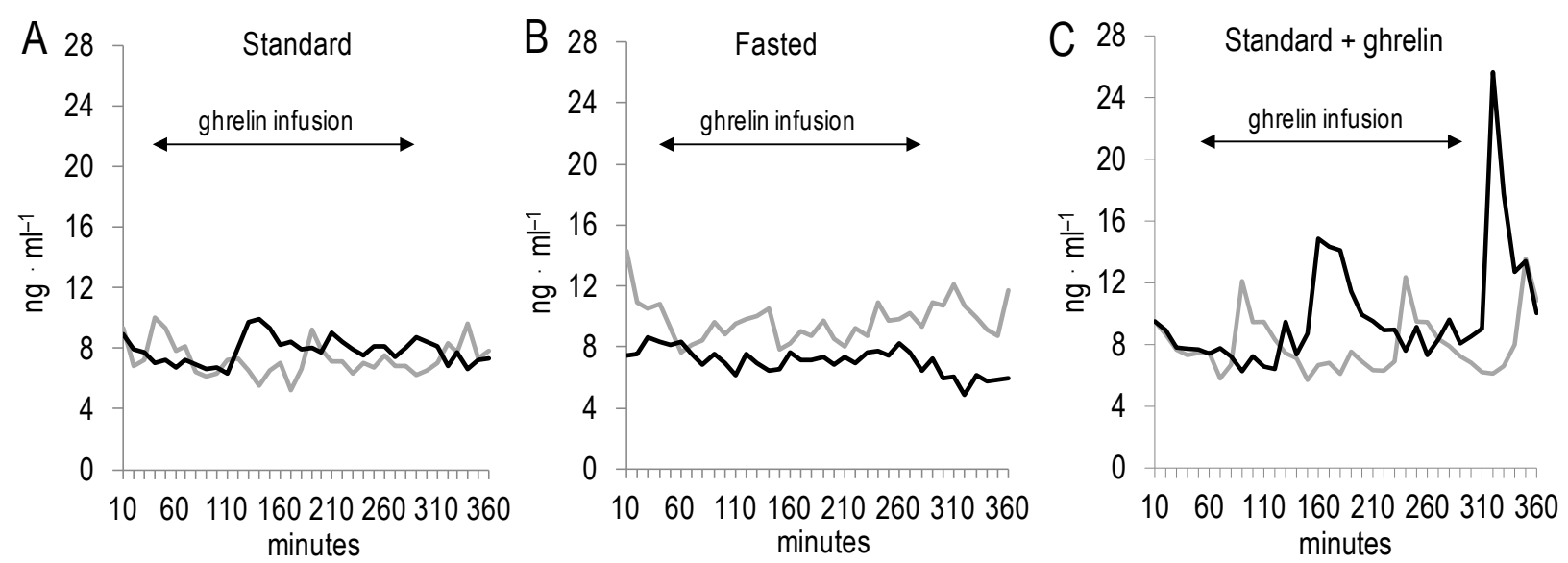

Figure 4. The pulsatile pattern of LH release in representative individual lambs on day 0 and day 3 of infusion when fed a standard diet and then infused intracereboventricularly with vehicle $(A)$ or fasted $72 \mathrm{~h}$ and then infused with vehicle $(B)$, or fed a standard diet and then infused with ghrelin (C)

\section{Discussion}

The presented data reveal that short-term starvation, as well as icv ghrelin infusions, induced similar changes in GnRH/LH secretory activity in peripubertal ewes. Both experimental treatments caused an increase in ir GnRH accumulation in the nerve terminals of the ME, which indicates inhibition of GnRH release into the portal vessels. Such an increase in ir LH accumulation in the secretory granules in the ME can reflect changes in gonadotropic cell secretory activity. Indeed, in our previous study we reported that in growing lambs, a long-term restricted protein diet resulted in an increase the number of ir LH-positive cells and a decreased plasma LH concentration (Polkowska et al., 2003). Similar results causing either cessation of LH pulses or a decrease in the concentration of circulating LH were also reported in ovariectomised ewes, immature female lambs, or in intact adult ewes subjected to an energy-restricted diet (Thomas et al., 1990; I'Anson et al., 2000; Polkowska et al., 2003; Wójcik-Gładysz et al., 2009). It is well established that in growthrestricted hypogonadotropic female sheep, impairment of GnRH secretion is a consequence of both diminished frequency and amplitude pulses (I'Anson et al., 2000). Moreover, similar changes in GnRH secretory activity were observed in long-term protein-restricted growing lambs, as well as in immature female lambs after short starvation (Polkowska and Przekop, 1993; Polkowska et al., 2006).

In the present study, intensive ir GnRH accumulation in the ME was observed in animals receiving exogenous ghrelin infusions, which demonstrates its inhibitory effects on GnRH release. In male rats, ghrelin treatment caused GnRH pulse frequency reduction (Lebrethon et al., 2006).
Furthermore, in hypothalamic fragments isolated from ovariectomised female rats, ghrelin significantly suppressed GnRH secretion (FernándezFernández et al., 2005b). The suppressive effect of ghrelin on reproductive activity due to the impairment of GnRH pulsatility was also reported in ovariectomised rhesus monkeys (Vulliémoz et al., 2004). Thus, the GnRH pulse generator appears to be the predominant target of ghrelin activity at the hypothalamic level. Since ghrelin receptors are distributed mainly in the ARC and VMN nuclei (Nakazato et al., 2001, Zigman et al., 2006), we suggest an indirect mode of ghrelin action on the GnRH neural system, involving intermediate neurons. Indeed, as a central orexigenic signal, ghrelin acts by affecting NPY, AgRP and orexin neuron activity (Kamegai et al., 2000; Toshinai et al., 2003), which leads to modulation of HPG axis activity. A direct stimulatory effect of exogenous ghrelin on NPY secretion in immature ewes was found in our previous research (Polkowska et al., 2012), which supports an indirect mode of ghrelin action on the GnRH network via enhancement of NPY neuronal system activity.

Our data have shown that exogenous ghrelin modified the activity of gonadotrops by increasing ir LH accumulation in secretory granules in the adenohypophysis. Moreover, increased GnRH and LH contents in the ME and gonadotrops, respectively, were not accompanied by changes in mean LH serum concentrations. Nevertheless, when the effects of exogenous ghrelin on LH pulse parameters were analysed, an increased amplitude with decreased pulse frequency was found. The ability of ghrelin to inhibit LH secretion appeared not to be dependent on the steroid hormone concentration, since this effect was observed at all stages of the oestrous cycle, as well as in ovariectomised female rats (Fernández-Fernández 
et al., 2005a). In adult ovariectomised monkeys or sheep, central or peripheral administration of ghrelin down-regulated LH release (Vulliémoz et al., 2004; Iqbal et al., 2006). Similarly, reduction of pulse amplitude and frequency without changes in mean LH concentration was observed in oestradiolimplanted castrated male sheep (Harrison et al., 2008). Interestingly, the suppressive effect of ghrelin was evident only after onset of puberty-ghrelin was ineffective in prepubertal female rats (FernándezFernández et al., 2004).

In the present study, short-term starvation or ghrelin administration did not affect LH $\beta$ mRNA expression, as demonstrated using two separate techniques: qRT-PCR and hybridization in situ. In contrast to the present results, a long-term protein restricted diet caused reduction of the LH mRNA level in the gonadotrops of growing female lambs (Polkowska et al., 2003). The lack of the effects of ghrelin or short-term starvation on LH $\beta$ gene expression indicates that the gonadotropic axis activity is not regulated by ghrelin in immature ewes just prior the first ovulation. In fact, at this stage of postnatal development, enhanced LH $\beta$ mRNA and ir LH expression in the gonadotropic cells and storage of the final protein product in the secretory granules of gonadotropic cells were found in sheep (Wańkowska and Polkowska, 2009). Taking into account the importance of peripubertal regulation for further successful reproductive activity, low gonadotrops sensitivity to some exogenous stimuli cannot be excluded. However, it must be emphasized that the experimental factors chosen in this experiment, i.e. $72 \mathrm{~h}$ fasting and applied ghrelin $\left(100 \mu \mathrm{g} \cdot\right.$ day $\left.^{-1}\right)$ were entirely sufficient to induce the response of somatotropic axis secretory activity under the same experimental design (Polkowska et al., 2011).

\section{Conclusions}

The obtained results revealed that administration of exogenous ghrelin affects the GnRH/LH axis mainly at the level of neurohormone/protein accumulation and LH pulsatility modifications in peripubertal ewes. As the reproductive axis is highly dependent on energy status, the action of ghrelin on the central level could be involved in the endocrine network that integrates energy balance and fertility in immature sheep.

\section{References}

Angelidis G., Dafopoulos K., Messini C. et al., 2013. Ghrelin: New insights into female reproductive system-associated disorders and pregnancy. Reprod. Sci. 19, 903-911
Barreiro M.L., Tena-Sempere M., 2004. Ghrelin and reproduction: a novel signal linking energy status and fertility? Mol. Cell Endocrinol. 226, 1-9

Breitschopf H., Suchanek G., Gould R.M. et al., 1992. In situ hybridisation with digoxigenin-labelled probes: sensitive and reliable detection method applied to myelinating rat brain. Acta Neuropathol. 84, 581-587

Cowley M. A., Smith R. G., Diano S. et al., 2003. The distribution and mechanism of action of ghrelin in the CNS demonstrates a novel hypothalamic circuit regulating energy homeostasis. Neuron 37, 649-661

D’Angelo-Bernard G., Moumni M., Jutisz M., Counis R., 1990. Cloning and sequence analysis of the cDNA for the precursor of the beta subunit of ovine luteinizing hormone. Nucl. Acid Res. 18,2175

Dubois M.-P., Dubois M.P., 1974. Mise en evidence par immunofluorescence de l'activite gonadotrope LH dans l'adenohypophyse foetale humaine. In: M.G. Forest, J. Bertrand (Editors). Sexual Endocrinology of the Perinatale Period, vol. 32. Colloques INSERM, Lyon, pp. 37-61

Fernandez-Fernandez R., Martini A.C., Navarro V.M., 2006. Novel signals for the integration of energy balance and reproduction. Mol. Cell Endocrinol. 254-255, 127-132

Fernández-Fernández R., Navarro V.M., Barriero M.L. et al., 2005a. Effects of chronic hyperghrelinemia on puberty onset and pregnancy outcome in rat. Endocrynology 146, 3018-3025

Fernández-Fernández R., Tena-Sempere M., Aguilar E., Pinilla L., 2004. Ghrelin effects on gonadotropin secretion in male and female rats. Neurosci. Lett. 362, 103-107

Fernández-Fernández R., Tena-Sempere M., Navarro V.M. et al., 2005b. Effects of ghrelin upon gonadotropin-releasing hormone and gonadotropin secretion in adult female rats: In vivo and in vitro studies. Neuroendocriology 82, 245-255

Harrison J.L., Miller D.W., Findlay P.A., Adam C.L., 2008. Photoperiod influences the central effects of ghrelin on food intake $\mathrm{GH}$ and LH secretion in sheep. Neuroendocrinology 87, 182-192

Iqbal J., Kurose Y., Canny B., Clarke I.J., 2006. Effects of central infusion of ghrelin on food intake and plasma levels of growth hormone, luteinizing hormone, prolactin, and cortisol secretion in sheep. Endocrinology 147, 510-519

I'Anson H., Manning J.M., Herbosa C.G. et al., 2000. Central inhibition of gonadotropin releasing hormone secretion in the growthrestricted hypogonadotropic female sheep. Endocrinology $141,520-527$

Kamegai J., Tamura H., Shimizu T. et al., 2000. Central effect of ghrelin, an endogenous growth hormone secretagogue, on hypothalamic peptide gene expression. Endocrinology 141, 4797-4800

Kojima M., Hosoda H., Date Y. et al., 1999. Ghrelin is a growth-hormone-releasing acylated peptide from stomach. Nature 402, 656-660

Korbonits M., Goldstone A.P., Gueorguiev M., Grossman A.B., 2004. Ghrelin- a hormone with multiple functions. Front. Neuroendocrinol. 25, 27-68

Lebrethon M.C., Aganina A., Fournier M. et al., 2006. Effects of in vivo and in vitro administration of ghrelin, leptin and neuropeptide mediators on pulsatile gonadotrophin-releasing hormone secretion from male rat hypothalamus before and after puberty. J. Neuroendocrinol. 19, 181-188

Liposits Z., Setalo G., Flerko G., 1984. Application of the silver-gold intensified 3, 3-diaminobenzidine chromogen to the light and electron microscopy detection of the luteinizing hormonereleasing hormone system in the rat brain. Neuroscience 13, 513-525 
Lorenzi T., Meli R., Marzioni D., 2009. Ghrelin: a metabolic signal affecting the reproductive system. Cytokine Growth Factor Rev. $20,137-152$

Merriam G.R., Wachter K.W., 1982. Algorithms for the study of episodic hormone secretion. Amer. J. Physiol. 243, E310E318

Miller D.W., Harrison J.L., Brown Y.A. et al., 2005. Immunohistochemical evidence for an endocrine/ paracrine role for ghrelin in the reproductive tissues of sheep. Reprod. Biol. Endocrinol. $3,60-74$

Muccioli G., Lorenzi T., Lorenzi M. et al., 2011. Beyond the metabolic role of ghrelin: A new player in the regulation of reproductive function. Peptides 32, 2514-2521

Nakazato M., Murakami N., Date Y. et al., 2001. A role for ghrelin in the central regulation of feeding. Nature 409, 194-198

Pelletier J., Counis R., de Reviers M.M., 1992. Localization of luteinizing hormone - $m$ RNA by in situ hybridization in the sheep pars tuberalis. Cell Tissue Res. 267, 267-306

Pelletier J., Counis R., de Reviers M.-M. et al., 1995. Changes in LHgene and $\mathrm{FSH}$-gene expression in the ram pars tuberalis according to season and castration. Cell Tissue Res. 281, 127-133

Polkowska J., Gajewska A., Wańkowska M., 2012. The effect of intracerebroventricular infusions of ghrelin or short fasting on the gene expression and immunoreactivity of neuropeptide $Y$ in the hypothalamic neurons in prepubertal female lambs: A morphofunctional study. J. Chem. Neuroanat. 46, $45-50$

Polkowska J., Lerrant Y., Wańkowska M. et al., 2003. The effect of dietary protein restriction on the secretion of $\mathrm{LH}$ and FSH in pre-pubertal female lambs. Anim. Reprod. Sci. 76, 53-66

Polkowska J., Przekop F., 1993. Effect of protein deficiency on luteinizing hormone releasing hormone (LHRH), gonadotropin releasing hormone associated peptide (GAP) and luteinizing hormone (LH) immunocytochemistry in the hypothalamus and pituitary gland of prepubertal ewes. Exp. Clin. Endocrinol. 101, 230-237

Polkowska J., Wańkowska M., Romanowicz K., 2011. The effect of intracerebroventricular infusion of ghrelin and/or short fasting on the gene expression and immunoreactivity of somatostatin in the hypothalamic neurons and on pituitary growth hormone in prepubertal female lambs. Brain Res. 1414, 41-49

Polkowska J., Wójcik-Gładysz A., Wańkowska M., 2006. The effect of intracerebroventricular infusions of leptin on the immunoreactivity of neuropeptide $Y$ and gonadotrophin releasing hormone neurons in the hypothalamus of prepubertal sheep in conditions of short fasting. J. Chem. Neuroanat. $32,65-73$

Schwartz N.B., 2000. Neuroendocrine regulation of reproductive cyclicity. In: P.M. Conn, M.E. Freeman (Editors). Neuroendocrinology in Physiology and Medicine. Totowa: Humana Press, pp. $135-146$
Shintani M., Ogawa Y., Ebihara K. et al., 2001. Ghrelin, an endogenous growth hormone secretagogue, is a novel orexigenic peptide that antagonizes leptin action through the activation of hypothalamic neuropeptide $\mathrm{Y} / \mathrm{Y} 1$ receptor pathway. Diabetes 50, 227-232

Stupnicki R., Kula E., 1982. Direct radioimmunoassay of progesterone in human plasma. Endokrinologie 80, 1-7

Stupnicki R., Madej A., 1976. Radioimmunoassay of LH in the blood plasma of farm animals. Endokrinologie 68, 6-13

Tena-Sempere M., 2007. Roles of ghrelin and leptin in the control of reproductive function. Neuroendocrinology $86,229-241$

Tena-Sempere M., Huhtaniemi I., 2003. Gonadotropins and gonadotropin receptors. In: B.C.J.M. Fauser (Editor). Reproductive Medicine: Molecular, Cellular and Genetic Fundamentals. Parthenon Publishing. New York, pp. 225-244

Thomas G.B., Mercer J.E., Karalis T. et al., 1990. Effect of restricted feeding on the concentrations of growth hormone $(\mathrm{GH})$, gonadotropins and prolactin (PRL) in plasma and on the amounts of messenger ribonucleic acid for $\mathrm{GH}$, gonadotropin subunit s and PRL in the pituitary glands of adult ovariectomized ewes. Endocrinology 126, 1361-1367

Toshinai K., Date Y., Murakami N. et al., 2003. Ghrelin-induced food intake is mediated via the orexin pathway. Endocrinology 144 , 1506-1512

Traczyk W., Przekop F., 1963. Methods of investigation of the function of the hypothalamus and hypophysis in chronic experiments in sheep. Acta. Physiol. Pol. 14, 217-226

Vulliémoz N.R., Xiao E., Xia-Zhang L. et al., 2004. Decrease in luteinizing hormone pulse frequency during a five-hour peripheral ghrelin infusion in the ovariectomized rhesus monkey. J. Clin. Endocrinol. Metab. 89, 5718-5723

Wańkowska M., Lerrant Y., Wójcik-Gładysz A. et al., 2002. Intracerebroventricular infusion of neuropeptide $Y$ up-regulates synthesis and accumulation of luteinizing hormone but not follicle stimulating hormone in the pituitary cells of prepubertal female lambs. J. Chem. Neuroanat. 23, 133-142

Wańkowska M., Polkowska J., 2009. The pituitary endocrine mechanisms involved in mammalian maturation: maternal and photoperiodic influences. Reprod. Biol. 10, 3-18

Welento J., Szteyn S., Milart Z., 1969. Observations on the stereotaxic configuration of the hypothalamic nuclei in the sheep. Anat. Anzeiger 124, 1-27

Wójcik-Gładysz A., Wańkowska M., Misztal T. et al., 2009. Effect of intracerebroventricular infusion of leptin on the secretory activity of the $\mathrm{GnRH} / \mathrm{LH}$ axis in fasted prepubertal lambs. Anim. Reprod. Sci. 114, 370-383

Wynne K., Stanley S., McGowan B., 2005. Appetite control. J. Endocrinol. 184, 291-318

Zigman J.M., Jones J.E., Lee C.E. et al., 2006. Expression of ghrelin receptor mRNA in the rat and the mouse brain. J. Comp. Neurol. $494,528-548$ 